\title{
Simulation and Optimization of Lead-Based Perovskite Solar Cells with Cuprous Oxide as a P-type Inorganic Layer
}

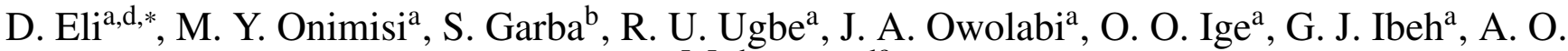 \\ Muhammed $^{\mathrm{c}}$
}

\author{
${ }^{a}$ Department of Physics, Nigerian Defence Academy, Kaduna, Nigeria \\ ${ }^{b}$ Department of Chemistry, Nigerian Defence Academy, Kaduna, Nigeria \\ ${ }^{c}$ Department of Physics, Bayero University, Kano, Nigeria \\ ${ }^{d}$ Department of Physical Sciences, Greenfield University, Kaduna, Nigeria
}

\begin{abstract}
The hole transporting material (HTM) is responsible for selectively transporting holes and blocking electrons which also plays a crucial role in the efficiency and stability of perovskite solar cells (PSCs). Spiro-MeOTAD is the most popular material, which is expensive and can be easily affected by moisture contents. There is need to find an alternative HTM with sufficiently high resistance to moisture content. In this paper, the influence of some parameters with cuprous oxide $\left(\mathrm{Cu}_{2} \mathrm{O}\right)$ as $\mathrm{HTM}$ was investigated using solar cell capacitance simulator (SCAPS). These include the influence of doping concentration and thickness of absorber layer, the effect of thickness of ETM and HTM as well as electron affinities of ETM and HTM on the performance of the PSCs. From the obtained results, it was found that concentration of dopant in absorber layer, thickness of ETM and HTM and the electron affinity of HTM and ETM affect the performance of the solar cell. The cell performance improves greatly with the reduction of ETM electron affinity and its thickness. Upon optimization of parameters, power conversion efficiency for this device was found to be $20.42 \%$ with current density of $22.26 \mathrm{mAcm}^{-2}$, voltage of $1.12 \mathrm{~V}$, and fill factor of $82.20 \%$. The optimized device demonstrates an enhancement of $58.80 \%, 2.25 \%, 20.40 \%$ and $30.23 \%$ in PCE, Jsc, FF and Voc over the initial cell. The results show that $\mathrm{Cu}_{2} O$ in lead-based PSC as HTM is an efficient system and an alternative to spiro-MeOTAD.
\end{abstract}

Keywords: Perovskite solar cells, inorganic HTM, device simulation, cuprous oxide, defect density

Article History :

Received: 26 April 2019

Received in revised form: 16 May 2019

Accepted for publication: 18 May 2019

Published: 30 August 2019

(C)2019 Journal of the Nigerian Society of Physical Sciences. All rights reserved. Communicated by: B. J. Falaye

\section{Introduction}

The ecxiting properties, including tuned band gap, small exciton energy, excellent bipolar carrier transport, long charge diffusion, and amazingly high tolerance to defects [1-7], perovskite halides have demonstrated promising abilities for a numerous of optoelectronic applications, including photovolataics,

${ }^{*}$ Corresponding author tel. no: +2348063307256

Email address: danladielibako@gmail.com (D. Eli ) light-emmision, photodetectors, $\mathrm{x}$-rays imaging, lasers, gamma ray detection etc [8-14].

Perovskite solar cells (PSCs) based on lead have demonstrated remarkable breakthrough in almost a decade since after its invention due to its advantages of low cost, high efficiency and simple fabrication process. Its efficiency has grown from $3.9 \%$ in 2009 to over $23 \%$ in late $2018[16,17]$. Despite its remarkable attainment, these power conversion efficiencies are still low as compared to inorganic solar cells such as crystalline silicon ( $c-S i, 25.7 \%)$, gallium arsenide ( $G a A s, 28.8 \%)$ 
etc [18]. Methyl ammonium lead iodide $\left(\mathrm{CH}_{3} \mathrm{NH}_{3} \mathrm{PbI}_{3}\right)$ with a band gap of $1.50 \mathrm{eV}$ that covers absorption within wide range of visible spectrum was reported by various experimental and theoretical studies $[18,19]$. Generally, PSC is made up of hole transporting layer, electron transporting layer and absorber layer. The function demonstrated by each layer in PSC should be understood in order to enhance the performance of the device [20].

The most routinely used electron transporting material (ETM) is $\mathrm{TiO}_{2}$ because of its suitable energy level for electron injection, high electron mobility, good stability and environmental friendliness $[3,4,7,18]$. It is often a difficult task to make good choice of hole transporting materials which are needed for extracting holes effectively from the perovskite layer while preventing electrons from recombination.

The most commonly used hole transport material is SpiroOMeTAD which is organic in nature [21]. It is made up of basically two additives, 4-tert-butylpyridine (TBP) and bis (trifluoromethane) sulfonamide lithium salt (Li-TFSI), which are used to improve the conductivity and hole mobility of spiroMeOTAD. The most commonly used HTM demonstrate hygroscopic nature, tendency to crystalize, and vulnerability to both moisture and heat, as such must be replaced with a cost effective and stable HTM having high hole mobility with ease of synthesis [18, 22, 23, 24].

Robust metal oxide [25, 26], carbon [27, 28], and other inorganic materials $[18,29]$ have shown outstanding behaviours in stabilizing the device, but in the meantime, the optimization of PCE in these devices is still necessary for accelerating the commercialization. Inorganic p-type semi-conductor such as $\mathrm{Cu}_{2} \mathrm{O}$ is considered to be an alternative to organic HTMs [30].

PCE has been greatly enhanced and reached up to $11.03 \%$ when $\mathrm{Cu}_{2} \mathrm{O}$ film was prepared via a facile process of $\mathrm{Cu}$ sputtering and controlled thermal oxidation [30, 31]. Except for experimental work, it is also equally important to investigate all aspects of the device theoretically in order to fully understand the device mechanism and optimize the device performance.

Considering $\mathrm{Cu}_{2} \mathrm{O}$ as HTM in lead based PSCs, very few works have been demonstrated so far. For example, perovskite $\left(\mathrm{CH}_{3} \mathrm{NH}_{3} \mathrm{PbI}_{3}\right)$ solar cells with $\mathrm{Cu}_{2} \mathrm{O}$ as $\mathrm{HTM}$ was simulated using SCAPS, while only the effect of thickness of the absorber on the performance of PSCs was investigated $[32,33]$. A device model that involve the simulation of various HTMs with $\mathrm{Cu}_{2} \mathrm{O}$ inclusive, was done but with no sufficient investigation on various parameters (only thickness of absorber) was carried out [34].

In addition to the thickness of the absorber, there are also many other important parameters which could affect the performance of PSCs. These include doping concentration in the absorber layer, thickness of the ETM and electron affinity of ETM and HTM. For example, proper choice of suitable electron affinity of ETM and HTM can prevent exiton quenching at the interface, thus can assist in enhancing device performance. As such, a comprehensive study of these parameters needs to be investigated in order to uncover further understanding and thus improve device performance. In this paper, simulation of lead based $\mathrm{CH}_{3} \mathrm{NH}_{3} \mathrm{PbI}_{3}$ PSCs with $\mathrm{Cu}_{2} \mathrm{O}$ as $\mathrm{HTM}$ and $\mathrm{TiO}_{2}$ as ETM was done with SCAPS. The influence of all above men- tioned parameters on the performance of PSCs were studied systematically.

\section{Device Simulation Parameters}

The structure of our simulated PSC is considered with layer configuration of glass substrate/TCO (transparent conducting oxide) $/ \mathrm{TiO}_{2}$ (ETM) absorber layer $\mathrm{CH}_{3} \mathrm{NH}_{3} \mathrm{PbI}_{3} / \mathrm{Cu}_{2} \mathrm{O}$ (HTM)/ metal back contact. The structure and the band diagram is shown in figure 1 (a) and (b). From the band structure, the valence band offset at the $\mathrm{CH}_{3} \mathrm{NH}_{3} \mathrm{PbI}_{3} / \mathrm{Cu}_{2} \mathrm{O}$ interface is $+0.08 \mathrm{eV}$, which can be considered beneficial for the flow of holes to the back-metal contact in order to avoid their recombination with the electrons in the perovskite layer.

The conduction band offset is $+0.30 \mathrm{eV}$ at the $\mathrm{TiO}_{2} / \mathrm{CH}_{3} \mathrm{NH}_{3}$ $\mathrm{PbI}_{3}$ interface, which is also necessary for the flow of photo excited electrons to the front electrode. Neutral Gaussian distribution defect is selected in the absorber layer and characteristic energy is set to be $0.1 \mathrm{eV}$ [18]. Two defect interfaces are inserted for carrier recombination. One defect interface is $\mathrm{TiO}_{2} / \mathrm{CH}_{3} \mathrm{NH}_{3} \mathrm{PbI}_{3}$ and the other one is $\mathrm{CH}_{3} \mathrm{NH}_{3} \mathrm{PbI}_{3} / \mathrm{Cu}_{2} O$.

The nature of the defect is set as Gaussian and defect density is set as $1 \times 10^{18} \mathrm{~cm}^{-3}[18,32]$. Table 1 shows the defect parameters which are used in the simulation. Basic parameters for each material used in the simulation are summarized in Table 2. Thermal velocities of hole and electron are selected as $107 \mathrm{cms}^{-1}[18,32,35,36]$. The optical reflectance is considered to be zero at the surface and at each interface [18]. Parameters are optimized in the study by using control variable method. The initial total defect density of the absorber layer is assumed to be $2.5 \times 10^{13} \mathrm{~cm}^{-3}$.

The current density-voltage curve has been drawn with these initial parameters as shown in Figure 2(A).

The short-circuit current density (Jsc) of $21.77 \mathrm{mAcm}^{-2}$, open-circuit voltage (Voc) of $0.865 \mathrm{~V}$, Fill Factor (FF) of $68.27 \%$, and PCE of $12.86 \%$ are obtained. The simulated device performance is consistent with the experimental results of lead-based PSCs $[30,31]$. This consistency shows that input parameters are valid and close to the real device. In the incident photonto-current efficiency (IPCE) of the device shown in figure 2(B) which is featured with a high platform between $300 \mathrm{~nm}$ and $850 \mathrm{~nm}$ with the maximum of $90 \%$ at $570 \mathrm{~nm}$. Optical absorption edge is red shifted to $800 \mathrm{~nm}$ which corresponds to a band gap of $1.55 \mathrm{eV}$ in $\mathrm{CH}_{3} \mathrm{NH}_{3} \mathrm{PbI}_{3}$. The IPCE covers the whole visible spectrum which is closer to the experimental work [30, 31].

\section{Results and Discussion}

\subsection{Influence of doping concentration $\left(N_{A}\right)$ of absorber layer}

In order to enhance the performance of solar cells, doping is a key process considered. Depending upon the type of dopants, doping can either be n-type or p-type. Like the other crystalline semiconductors, the shallow point defects in absorber could cause unintentional doping at room temperature. The performance of PSC can be enhanced by introducing appropriate 
Table 1: Defect parameters of interfaces and absorber [18, 32]

\begin{tabular}{lccc}
\hline Parameters & $\mathrm{CH}_{3} \mathrm{NH}_{3} \mathrm{PbI}_{3}$ & $\mathrm{TiO}_{2} / \mathrm{CH}_{3} \mathrm{NH}_{3} \mathrm{PbI}_{3}$ interface & $\mathrm{CH}_{3} \mathrm{NH}_{3} \mathrm{PbI}_{3} / \mathrm{Cu}_{2} \mathrm{O}_{\text {interface }}$ \\
\hline Defect type & Neutral & Neutral & Neutral \\
Capture cross section for electrons $\left(\mathrm{cm}^{2}\right)$ & $2 \times 10^{-15}$ & $2 \times 10^{-16}$ & $2 \times 10^{-15}$ \\
Capture cross section for holes $\left(\mathrm{cm}^{2}\right)$ & $2 \times 10^{-15}$ & $2 \times 10^{-16}$ & $2 \times 10^{-15}$ \\
Energetic distribution & Gaussian & Single & Single \\
Energetic level with respect to Ev $(\mathrm{eV})$ & 0.500 & 0.650 & 0.650 \\
Characteristic energy $(\mathrm{eV})$ & 0.1 & 0.1 & 0.1 \\
Total density $\left(\mathrm{cm}^{-3}\right)$ & $1 \times 10^{15}-1 \times 10^{19}$ & $1 \times 10^{18}$ & $1 \times 10^{18}$ \\
\hline
\end{tabular}

Table 2: Simulation parameters of PSCs devices

\begin{tabular}{|c|c|c|c|c|}
\hline Parameters & FTO & ETM $\left(\mathrm{TiO}_{2}\right)$ & Absorber & HTM $\left(\mathrm{Cu}_{2} \mathrm{O}\right)$ \\
\hline Thickness $(\mu m)$ & 0.4 & 0.05 & 0.45 & 0.15 \\
\hline Band gap energy $\operatorname{Eg}(e V)$ & 3.5 & $3.26[32]$ & $1.55[32]$ & $2.17[32]$ \\
\hline Electron affinity $\chi(\mathrm{eV})$ & 4.0 & $4.2[32]$ & $3.9[18]$ & $3.2[32]$ \\
\hline Relative permittivity $\epsilon_{r}$ & 9 & 10 & 6.5 & $7.11[32]$ \\
\hline Effective conduction band density $N_{c}\left(\mathrm{~cm}^{-3}\right)$ & $2.2 \times 10^{18}$ & $2.2 \times 10^{18}[32]$ & $2.2 \times 10^{18}[32]$ & $2.2 \times 10^{18}[32]$ \\
\hline Effective valance band density $N_{v}\left(\mathrm{~cm}^{-3}\right)$ & $2.2 \times 10^{18}$ & $2.2 \times 10^{18}[32]$ & $2.2 \times 10^{18}[32]$ & $2.2 \times 10^{18}[32]$ \\
\hline Electron mobility $\mu n\left(\mathrm{~cm}^{2} V^{-1} \mathrm{~s}^{-1}\right)$ & 20 & $20[18,32]$ & $2[32,33]$ & $80[32,39]$ \\
\hline Hole mobility $\mu p\left(\mathrm{~cm}^{2} V^{-1} \mathrm{~s}^{-1}\right)$ & 10 & $10[18,32]$ & $2[32,33]$ & $80[32,39]$ \\
\hline Donor concentration ND $\left(\mathrm{cm}^{-3}\right)$ & $1 \times 10^{19}$ & $1 \times 10^{17}$ & 0 & 0 \\
\hline Acceptor concentration NA $\left(\mathrm{cm}^{-3}\right)$ & 0 & 0 & $1 \times 10^{13}[7,32]$ & $1 \times 10^{18}[18,32]$ \\
\hline Defect density Nt $\left(\mathrm{cm}^{-3}\right)$ & $1 \times 10^{15}$ & $1 \times 10^{15}[18,32]$ & $2.5 \times 10^{13}[18,32]$ & $1 \times 10^{15}[18,32]$ \\
\hline
\end{tabular}
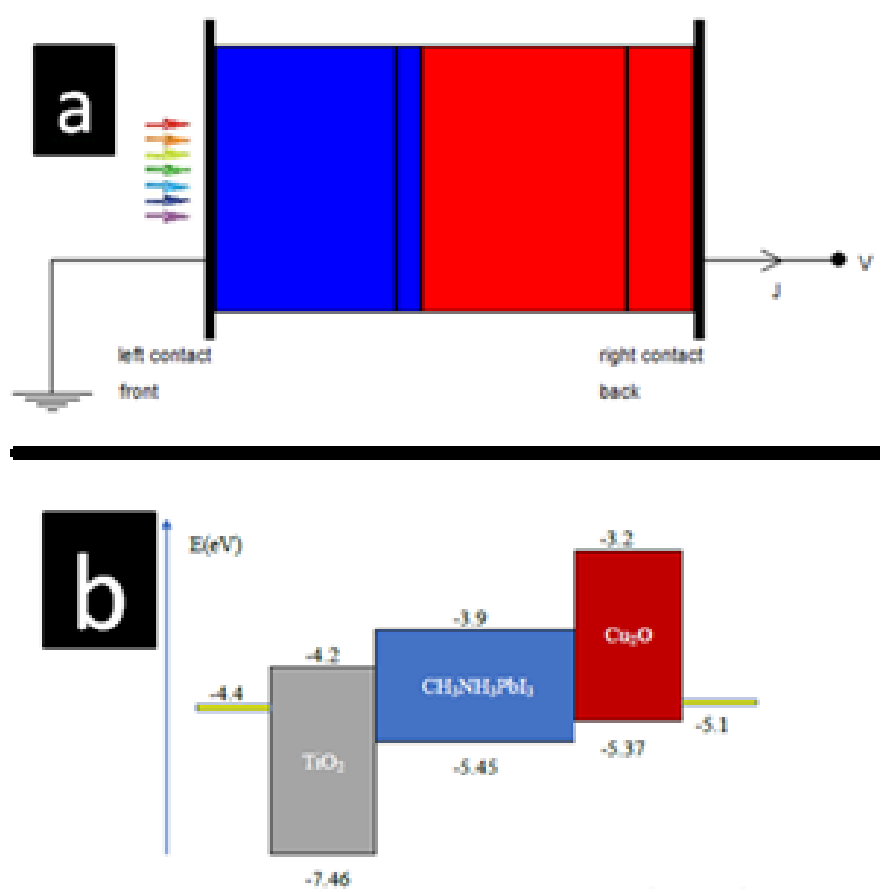

Figure 1: (a) The structure of perovskite solar cell in the simulation and (b) Energy level diagram of $\mathrm{Cu}_{2} \mathrm{O}$ in the device

dopant in absorber layer [18, 37]. The self-doping process can be adopted for $\mathrm{n}$ - or p-type doping in absorber layer. It has been demonstrated experimentally that $\mathrm{n}$-type or $\mathrm{p}$-type self-doping in $\mathrm{CH}_{3} \mathrm{NH}_{3} \mathrm{PbI}_{3}$ lead towards the manipulation of carrier density, majority carrier type and charge transport by changing the thermal annealing or precursor ratios in the solutions [37, 38].

Formation of $\mathrm{CH}_{3} \mathrm{NH}_{3} \mathrm{PbI}_{3}$ involves organic and inorganic precursors named methyl ammonium iodide (MAI) and lead iodide $\left(\mathrm{PbI}_{2}\right)$. The ratio between precursors $\left(\mathrm{PbI}_{2} / \mathrm{MAI}\right)$ decides the doping of the absorber. Upon thermal annealing, $\mathrm{PbI}_{2}$ rich absorber layer is n-doped and $\mathrm{PbI}_{2}$ deficit absorber layer is pdoped [39]. Furthermore, $\mathrm{CH}_{3} \mathrm{NH}_{3} \mathrm{PbI}_{3}$ is unstable in air and humidity.

When moist air comes in contact with device then $\mathrm{PbI}_{2}$ is generated and oxidation state of lead is changed. This process is the cause of introducing impurities in absorber layer. The effect of doping concentration on the performance of perovskite solar cell is studied by choosing the values of $N_{A}$ in the range of $10^{14}-10^{17} \mathrm{~cm}^{-3}$. Table 3 gives the PCE of PSC with various values of doping concentration. It is worth noting that PCE is maximum when the value of $N_{A}$ is $1 \times 10^{15} \mathrm{~cm}^{-3}$. Jsc also has the same behaviour. The results above demonstrate that charge carriers are transported and collected more efficiently at the same irradiance when $N_{A}$ of the absorber is $1 \times 10^{15} \mathrm{~cm}^{-3}$.

Therefore, proper selection of $N_{A}$ is necessary for the improvement of performance of PSCs. On the other hand, Jsc and Voc decrease when values of $N_{A}$ increases beyond $1 \times 10^{15} \mathrm{~cm}^{-3}$. The variation in the cell performance with the doping concentration can be explained in terms of built-in electric field which is enhanced with the increase of doping concentration. The charge carriers are separated and increased by the increase of electric field resulting in the enhanced performance of PSCs $[18,40]$.

The decrease in Jsc with increasing doping concentration could be explained from the perspective of Auger recombina- 

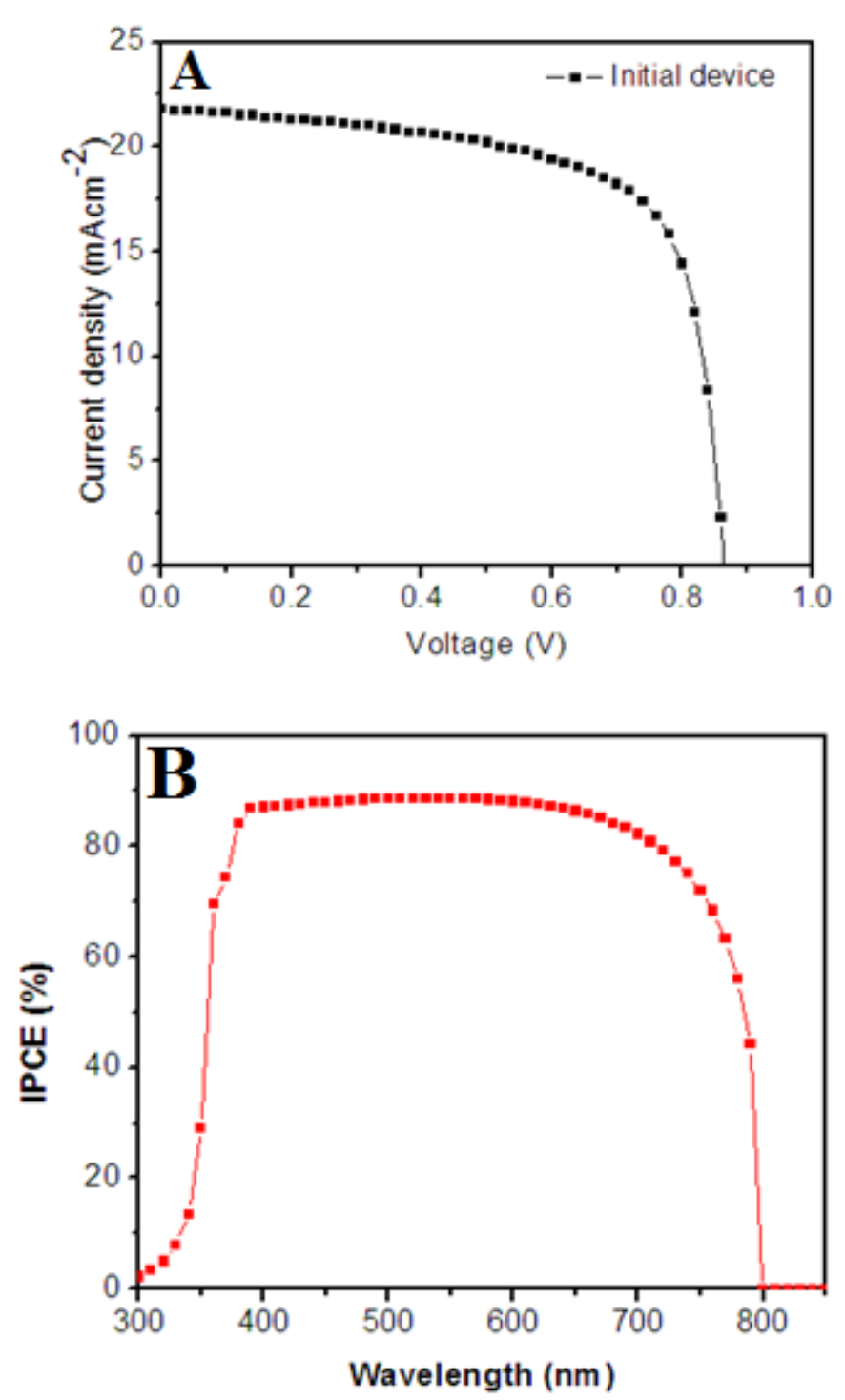

Figure 2: (A) J-V curve of PSC with initial parameters, (B) IPCE spectra of the device with initial parameters

tion. Auger recombination rate increases with further increase of doping density beyond $1 \times 10^{15} \mathrm{~cm}^{-3}$. It is also clear that total recombination rate also increases when doping density increases beyond $1 \times 10^{15} \mathrm{~cm}^{-3}$. The scattering and recombination increases due to increasing doping density thus suppressing hole transportation $[18,41]$. Therefore, optimum doping density enhances the Voc and Jsc which in turn increases the PCE. While further increase in doping density is not favourable due to high recombination and scattering.

There should be lower carrier concentration in lead perovskite so that carrier mobility can increase within the absorber. The optimum performance with Jsc of $22.10 \mathrm{mAcm}^{-2}$, Voc of $0.85 \mathrm{~V}, \mathrm{FF}$ of $73.97 \%$ and PCE of $13.82 \%$ is obtained under the doping density of $1 \times 10^{15} \mathrm{~cm}^{-3}$. The comparison is shown between $\mathrm{J}-\mathrm{V}$ curves with different value of $N_{A}$ in Figure 3(B). With the optimization, PCE was enhanced by $7.38 \%$, and Jsc increases $1.52 \%$, as compared with the device having initial value of $N_{A}=1 \times 10^{13} \mathrm{~cm}^{-3}$. Figure 3(A) shows the simulation results by changing the value of doping concentration from $1 \times 10^{15}$ to $1 \times 10^{17} \mathrm{~cm}^{-3}$ with respect to photovoltaic parameters (PCE, Voc, Jsc, and FF).
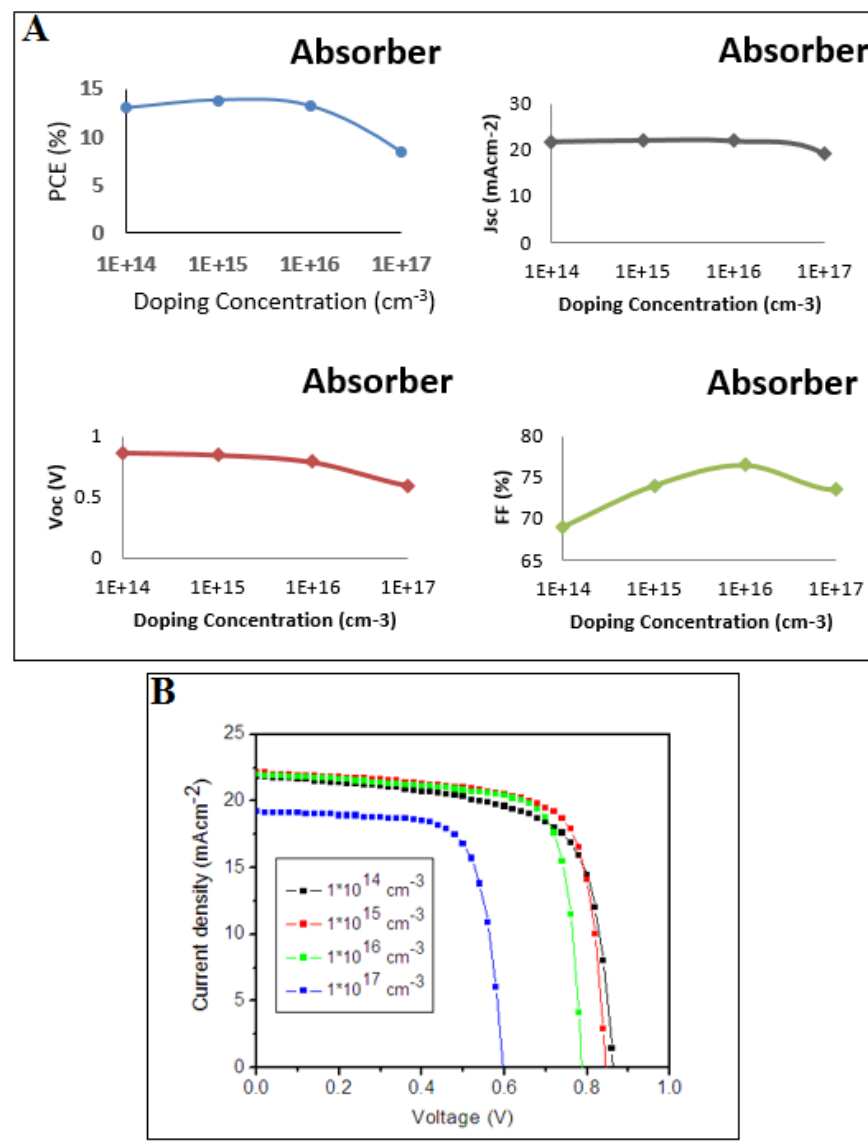

Figure 3: (A) Variation in performance parameters of PSC with doping concentration of absorber, (B) J-V curves of PSC with different values of doping concentration.

\subsection{Influence of electron affinity of ETM and HTM}

One of the important factor considered in $\mathrm{TiO}_{2} /$ perovskite/ $\mathrm{Cu}_{2} \mathrm{O}$ is band offset which becomes a determining factor as to the carrier recombination at the interface and is the measure of Voc. By varying the values of electron affinities of $\mathrm{TiO}_{2}(3.7-4.3 \mathrm{eV})$ and $\mathrm{Cu}_{2} \mathrm{O}(3.1-3.7 \mathrm{eV})$, the band offset can be adjusted. Figures 4(A) and 5(A) show variation of PCE, Voc, Jsc and FF with electron affinity of ETM and HTM respectively. The values of $3.7 \mathrm{eV}$ and $3.3 \mathrm{eV}$ give the best $\mathrm{PCE}$ for $\mathrm{TiO}_{2}$ and $\mathrm{Cu}_{2} \mathrm{O}$ respectively. When the electron affinity of ETM is high (greater than $3.7 \mathrm{eV}$ ), then Voc and Jsc decrease slightly. PCE of $20.29 \%$, Jsc of $22.55 \mathrm{mAcm}^{-2}$, Voc of $1.10 \mathrm{~V}$ and FF of $81.72 \%$ were obtained upon optimizing value of electron affinity of ETM, as shown in Table 4 and PCE of $13.11 \%$, Jsc of $21.87 \mathrm{mAcm}^{-2}$, Voc of $0.87 \mathrm{~V}$ and FF of $69.31 \%$ were obtained upon optimizing value of electron affinity of HTM, as shown in Table 5. It is evident that proper ETM and HTM selection with suitable electron affinity can reduce the recombination of car- 
Table 3: Dependence of solar cell performance on the doping concentration of Absorber layer

\begin{tabular}{lcccc}
\hline Parameters $N_{A}\left(\mathrm{~cm}^{-3}\right)$ & Jsc $\left(m A \mathrm{~cm}^{-2}\right)$ & Voc $(V)$ & FF & PCE $(\%)$ \\
\hline $10^{14}$ & 21.80 & 0.86 & 69.02 & 12.99 \\
$10^{15}$ & 22.80 & 0.85 & 73.97 & 13.82 \\
$10^{16}$ & 21.96 & 0.79 & 76.43 & 13.21 \\
$10^{17}$ & 19.20 & 0.60 & 73.45 & 8.40 \\
\hline
\end{tabular}

riers and performance of PSCs can further be optimised [42].
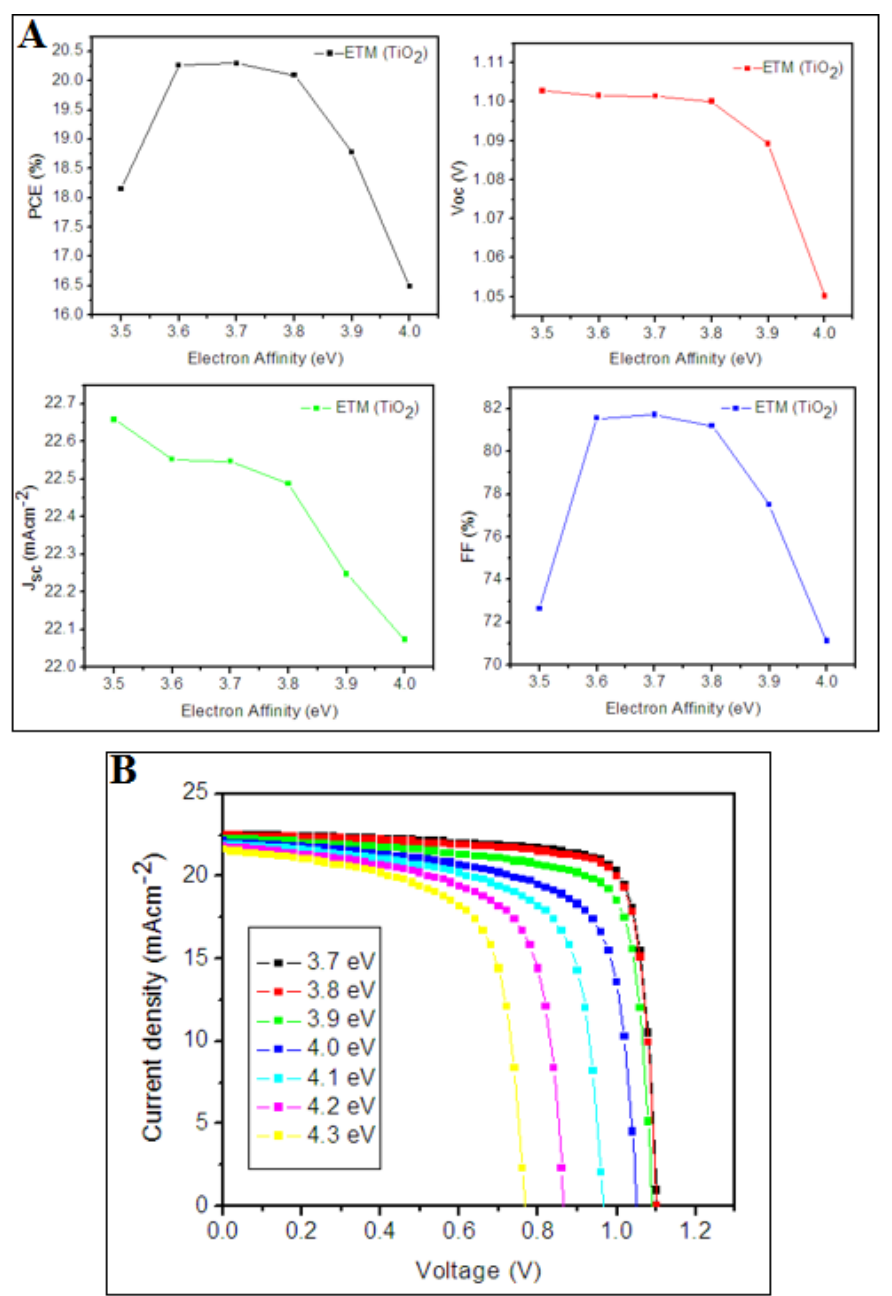

Figure 4: (A) Variation in performance parameters of PSC with electron affinity of ETM, (B) J-V curves of PSC with different values of electron affinity of ETM.

\subsection{Influence of thickness of ETM and HTM}

Figure 6(A) is the plot of solar cell parameters; $V_{O C}, J_{S C}$, $\mathrm{FF}$ and PCE versus thickness of the ETM; $\mathrm{TiO}_{2}$. In both cases $V_{O C}, J_{S C}, \mathrm{FF}$ and PCE are gradually decreasing due to fractional absorption of incident light by the $\mathrm{TiO}_{2}$ layer, the bulk recombination and surface recombination at the interface [15]. Thickness of ETMs has been varied from 0.001 to $0.160 \mu \mathrm{m}$ which shows a decrease in photovoltaic parameters with increase in ETM thickness, as shown in Table 6. Similarly, Fig-
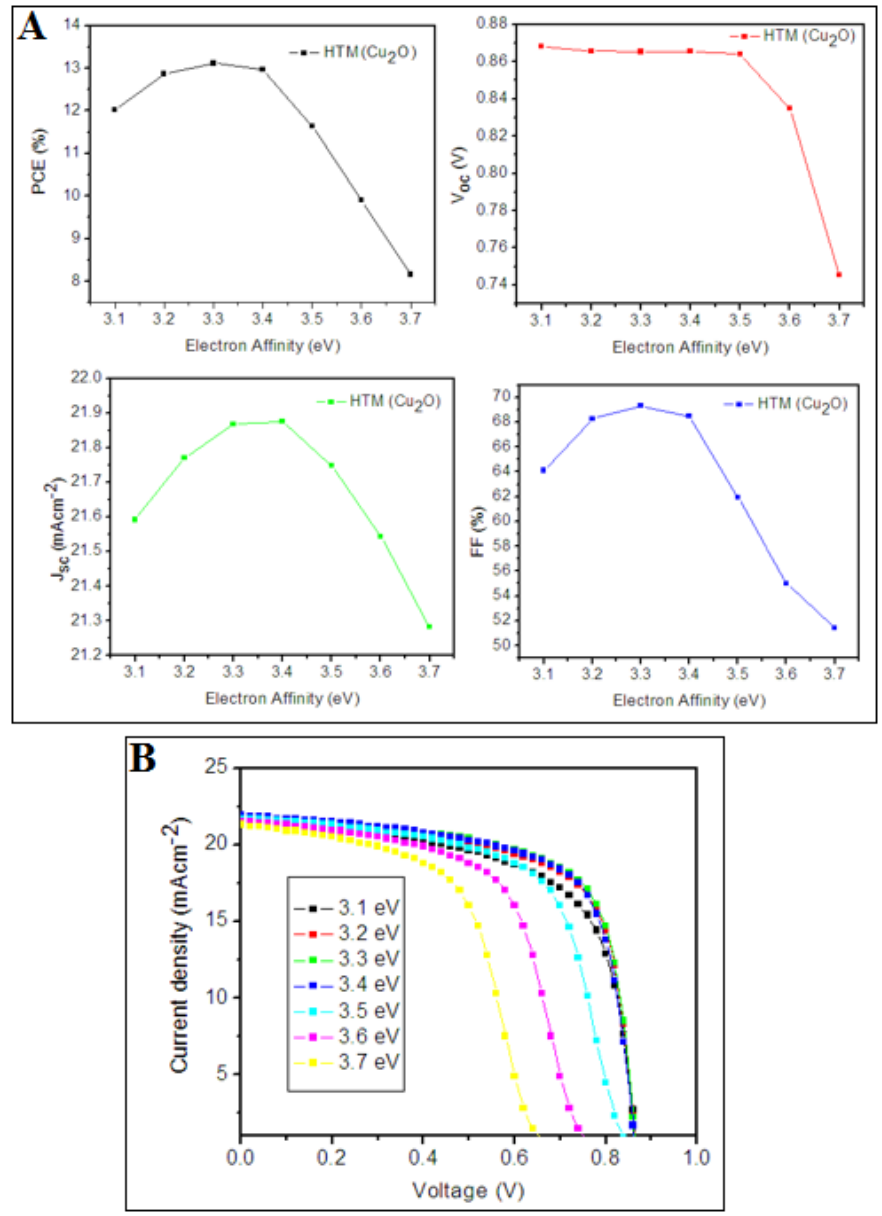

Figure 5: (A) Variation in performance parameters of PSC with electron affinity of HTM, (B) J-V curves of PSC with different values of electron affinity of HTM.

ure 6(B) shows reverse case as $V_{O C}, J_{S C}$, FF and PCE increase with increase in HTM up to $0.02 \mu \mathrm{m}$. Above $0.02 \mu \mathrm{m}$ we noticed a constant value for $V_{O C}, J_{S C}$, FF and PCE, which means the thickness that gives optimum performance is from 0.04 to $0.16 \mu \mathrm{m}$. The slightly increase with increase in thickness up to $0.02 \mu \mathrm{m}$ suggests the higher conductivity of the $\mathrm{TiO}_{2}$ and partial absorption of the light. PCE of $15.52 \%$, Jsc of $22.10 \mathrm{mAcm}^{-2}$, $V_{O C}$ of $1.01 \mathrm{~V}$ and FF of $69.81 \%$ are obtained at a thickness of $0.001 \mu \mathrm{m}$ which is the optimized value of HTM thickness and PCE of $12.87 \%, J_{S C}$ of $21.77 \mathrm{mAcm}^{-2}, V_{O C}$ of $0.87 \mathrm{~V}$ and FF of $68.27 \%$ are obtained, as shown in Table 7. 
Table 4: Dependence of solar cell performance on the electron affinity of ETM

\begin{tabular}{lcccc}
\hline Parameters $E A(\mathrm{eV})$ & $\mathbf{J s c}\left(\mathrm{mAcm}^{-2}\right)$ & Voc $(\mathrm{V})$ & $\mathbf{F F}$ & PCE $(\%)$ \\
\hline 3.7 & 22.50 & 1.10 & 81.72 & 20.29 \\
3.8 & 22.49 & 1.10 & 81.20 & 20.10 \\
3.9 & 22.25 & 1.09 & 77.50 & 18.78 \\
4.0 & 22.07 & 1.05 & 71.14 & 16.49 \\
4.1 & 21.93 & 0.97 & 69.21 & 14.64 \\
4.2 & 21.77 & 0.87 & 68.27 & 12.87 \\
4.3 & 21.58 & 0.77 & 67.36 & 11.13 \\
\hline
\end{tabular}

Table 5: Dependence of solar cell performance on the HTM

\begin{tabular}{lcccc}
\hline Parameters $E A(\mathrm{eV})$ & $\mathbf{J s c}\left(\mathrm{mAcm}^{-2}\right)$ & Voc $(\mathrm{V})$ & $\mathbf{F F}$ & PCE (\%) \\
\hline 3.1 & 21.59 & 0.87 & 64.10 & 12.01 \\
3.2 & 21.77 & 0.87 & 68.27 & 12.87 \\
3.3 & 21.87 & 0.87 & 69.31 & 13.11 \\
3.4 & 21.88 & 0.87 & 68.48 & 12.96 \\
3.5 & 21.74 & 0.86 & 61.94 & 11.64 \\
3.6 & 21.54 & 0.83 & 55.03 & 9.90 \\
3.7 & 21.28 & 0.75 & 51.43 & 8.16 \\
\hline
\end{tabular}

Table 6: Dependence of solar cell performance on the ETM

\begin{tabular}{lcccc}
\hline Parameters $T(\mu \mathrm{m})$ & $\mathbf{J s c}\left(\mathrm{mAcm}^{-2}\right)$ & Voc $(V)$ & FF & PCE $(\%)$ \\
\hline 0.0010 & 22.10 & 1.01 & 69.81 & 15.52 \\
0.0025 & 22.05 & 0.97 & 69.37 & 14.89 \\
0.0050 & 22.00 & 0.95 & 69.12 & 14.37 \\
0.0100 & 21.93 & 0.91 & 69.84 & 13.81 \\
0.0200 & 21.86 & 0.89 & 68.50 & 13.27 \\
0.0400 & 21.79 & 0.87 & 68.33 & 12.93 \\
0.0800 & 21.73 & 0.86 & 68.27 & 12.81 \\
0.1600 & 21.64 & 0.86 & 68.30 & 12.76 \\
\hline
\end{tabular}

Table 7: Dependence of solar cell performance on the HTM

\begin{tabular}{lcccc}
\hline Parameters $T(\mu \mathrm{m})$ & $\mathbf{J s c}\left(\mathrm{mAcm}^{-2}\right)$ & Voc $(V)$ & FF & PCE (\%) \\
\hline 0.0010 & 21.23 & 0.82 & 55.61 & 9.66 \\
0.0025 & 21.24 & 0.82 & 55.73 & 9.76 \\
0.0050 & 21.29 & 0.84 & 56.41 & 10.12 \\
0.0100 & 21.51 & 0.87 & 62.00 & 11.58 \\
0.0200 & 21.76 & 0.87 & 68.15 & 12.84 \\
0.0400 & 21.77 & 0.87 & 68.27 & 12.87 \\
0.0800 & 21.77 & 0.87 & 68.27 & 12.87 \\
0.1600 & 21.77 & 0.87 & 68.27 & 12.87 \\
\hline
\end{tabular}

Table 8: Dependence of solar cell performance on the Absorber

\begin{tabular}{lcccc}
\hline Parameters $T(\mu m)$ & Jsc $\left(m A c m^{-2}\right)$ & Voc $(V)$ & FF & PCE $(\%)$ \\
\hline 0.2 & 17.57 & 0.83 & 74.16 & 10.78 \\
0.3 & 20.32 & 0.85 & 71.75 & 12.32 \\
0.4 & 21.43 & 0.86 & 69.51 & 12.83 \\
0.5 & 21.99 & 0.87 & 67.05 & 12.82 \\
0.6 & 22.20 & 0.87 & 64.72 & 12.52 \\
0.7 & 22.21 & 0.88 & 62.50 & 12.22 \\
0.8 & 22.10 & 0.88 & 60.48 & 11.82 \\
0.9 & 21.93 & 0.87 & 58.67 & 11.41 \\
\hline
\end{tabular}


Table 9: Optimized Parameters of the device

\begin{tabular}{lccc}
\hline Optimized parameters & ETM $\left(\mathrm{TiO}_{2}\right)$ & Absorber $\left(\mathrm{CH}_{3} \mathrm{NH}_{3} \mathrm{PbI}_{3}\right)$ & $\mathbf{H T M}\left(\mathrm{Cu}_{2} \mathrm{O}\right)$ \\
\hline Doping density $\left(\mathrm{cm}^{-3}\right)$ & - & $1 \times 10^{15}$ & - \\
Electron affinity $(\mathrm{eV})$ & 3.7 & - & 3.3 \\
Thickness $(\mu \mathrm{m})$ & 0.0010 & 0.4000 & 0.1600 \\
\hline
\end{tabular}

Table 10: Photovoltaic parameters of $\mathrm{Cu}_{2} \mathrm{O}$ based perovskite solar cells reported in the experimental work in the literature and simulated results using SCAPS.

\begin{tabular}{lcccc}
\hline Simulation & $\mathbf{J s c}\left(\mathrm{mAcm}^{-2}\right)$ & Voc $(V)$ & FF & PCE (\%) \\
\hline Initial & 21.76 & 0.86 & 68.26 & 12.86 \\
Optimized $N_{A}$ of absorber & 22.09 & 0.85 & 73.97 & 13.82 \\
Optimized thickness of absorber & 21.43 & 0.86 & 69.51 & 12.83 \\
Optimized EA of ETM & 22.55 & 1.10 & 81.72 & 20.29 \\
Optimized EA of HTM & 21.87 & 0.87 & 69.31 & 13.11 \\
Optimized thickness of ETM & 22.10 & 1.00 & 69.81 & 15.52 \\
Optimized thickness of HTM & 21.77 & 0.87 & 68.27 & 12.87 \\
Final optimization & 22.26 & 1.12 & 82.20 & 20.42 \\
[30] & 17.50 & 0.95 & 66.20 & 11.03 \\
[31] & 19.02 & 0.99 & 73.63 & 13.97 \\
\hline
\end{tabular}
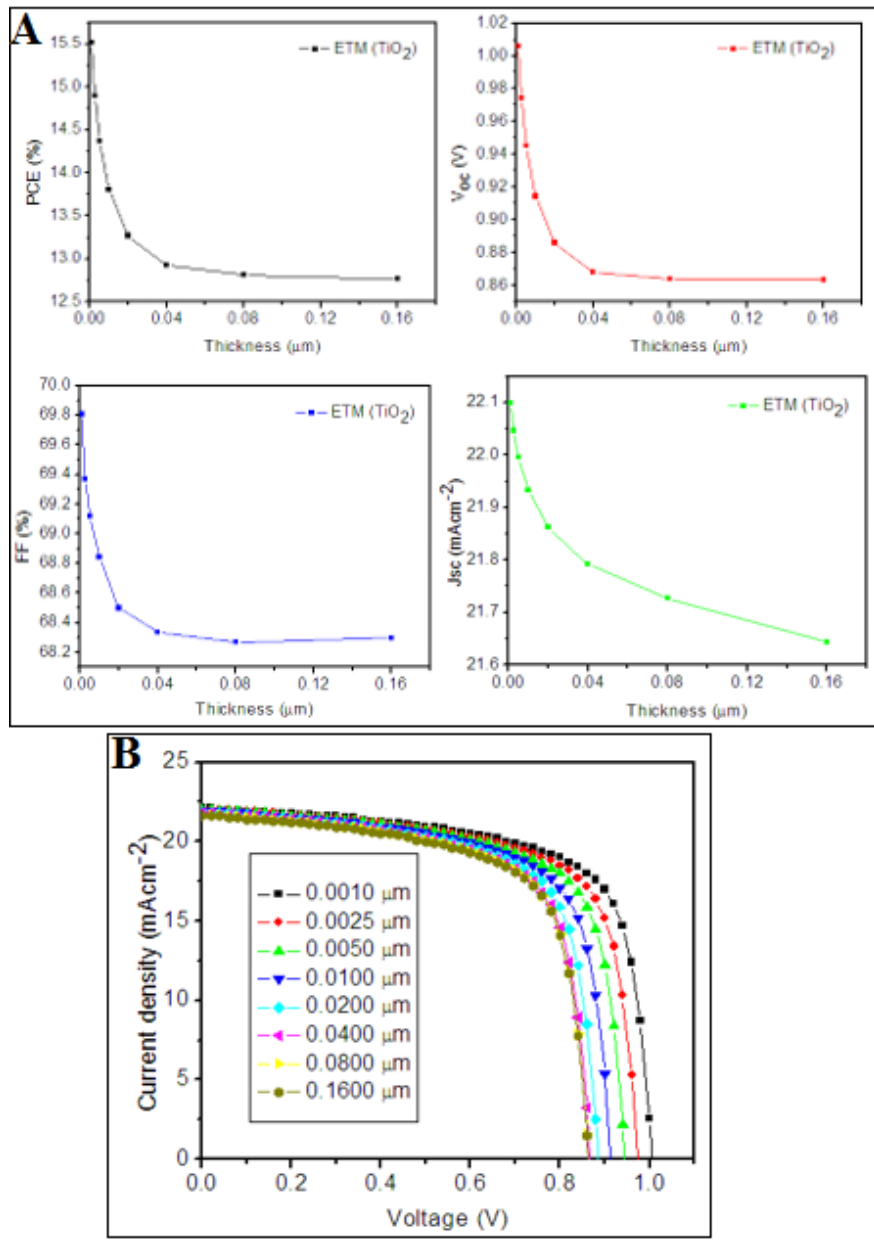

Figure 6: (A) Variation in performance parameters of PSC with thicknss of ETM, (B) J-V curves of PSC with different values of thickness of ETM.
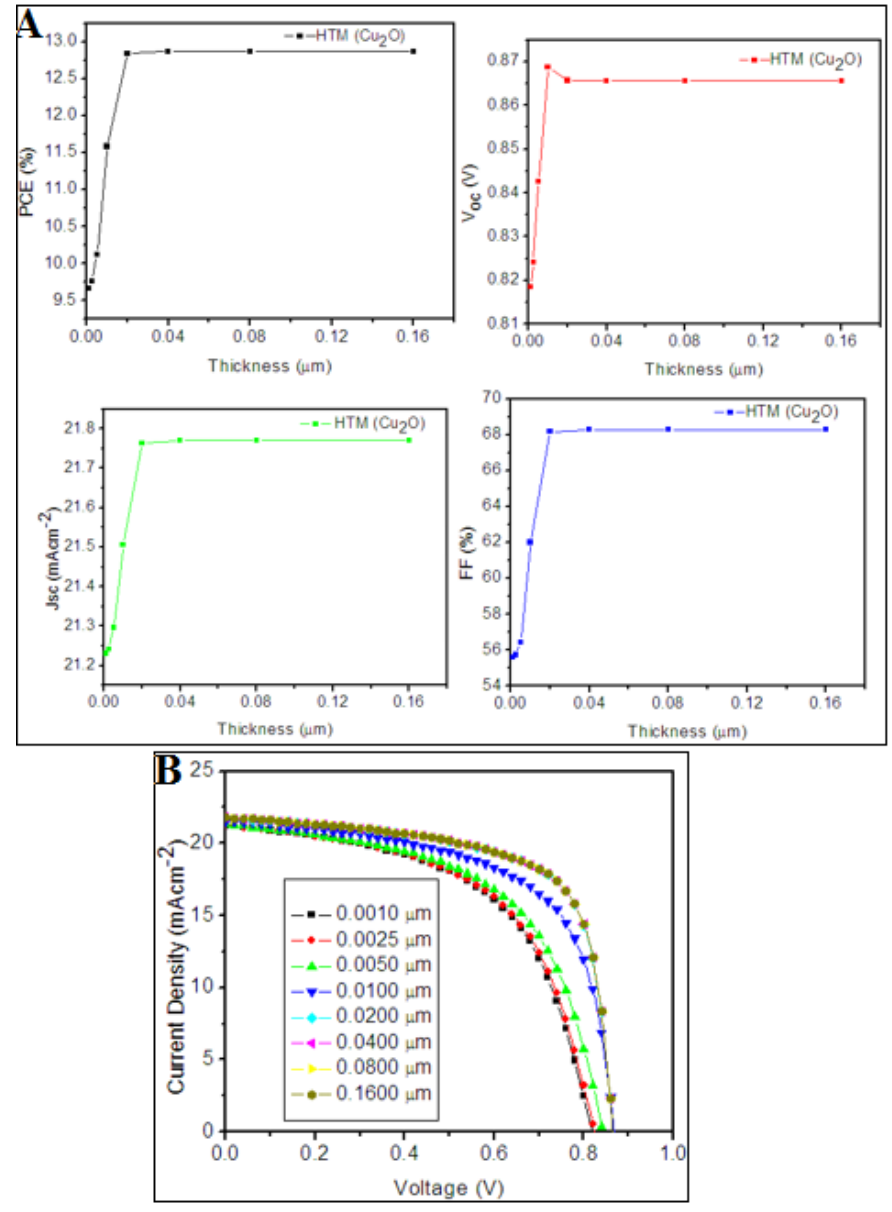

Figure 7: (A) Variation in performance parameters of PSC with thickness of HTM, (B) J-V curves of PSC with different values of thickness of HTM.

\subsection{Influence of thickness of absorber layer}

There is another parameter, thickness of absorber layer, which 78 affects the performance of solar cell. The influence of thickness 

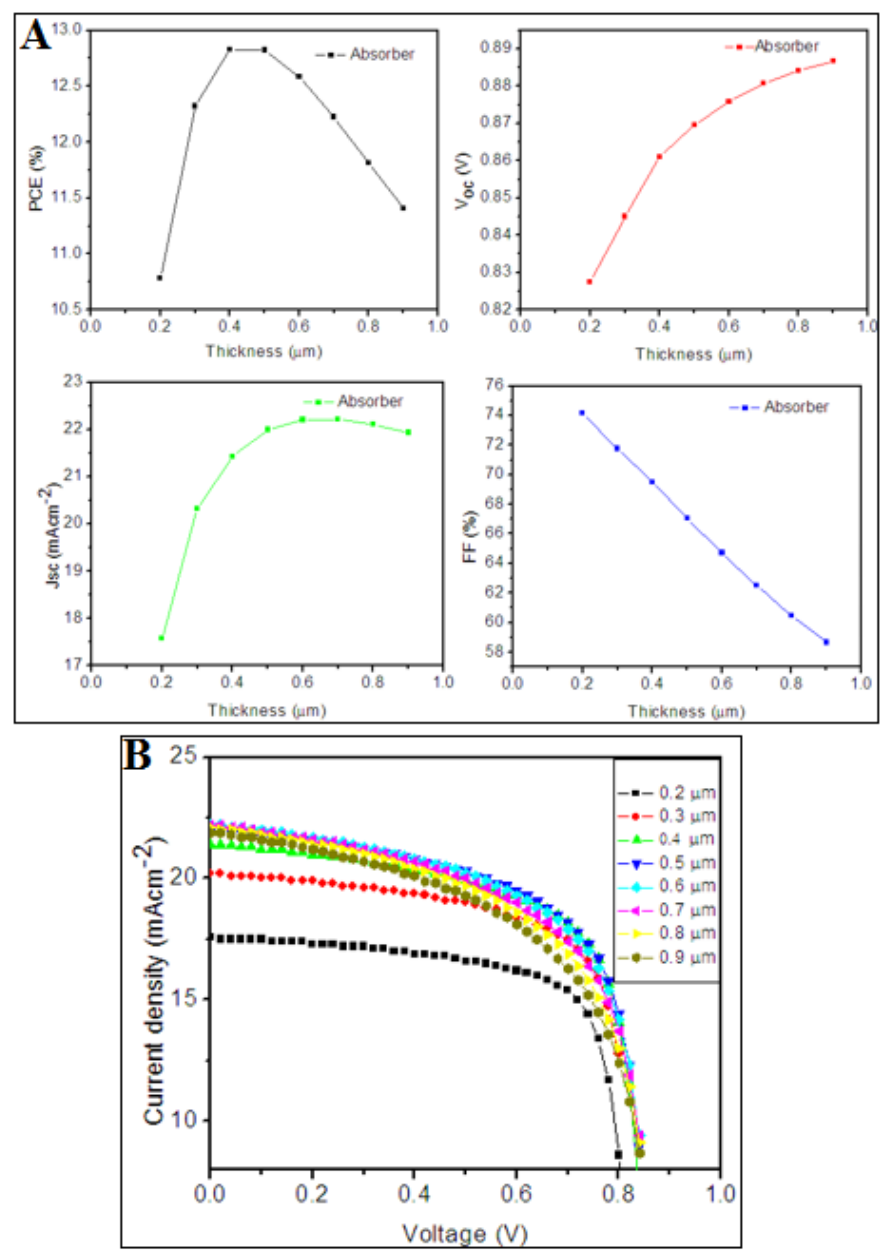

Figure 8: (A) Variation in performance parameters of PSC with thickness of Absorber, (B) J-V curves of PSC with different values of Absorber thickness.

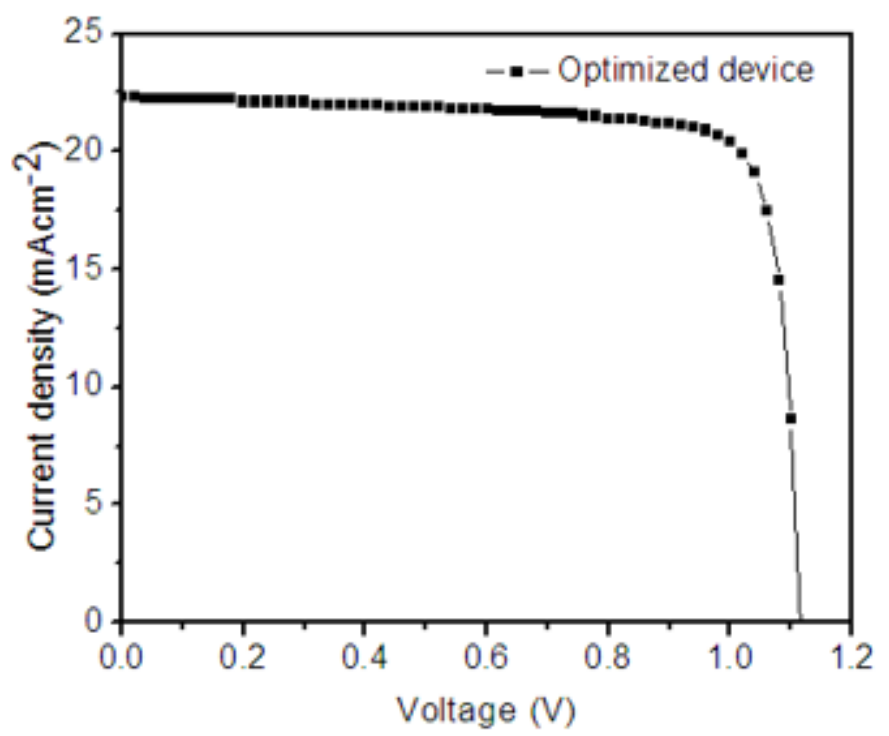

Figure 9: J-V curves of PSC with Optimized parameters. of absorber on the solar cell parameters; $V_{O C}, J_{S C}, \mathrm{FF}$ and PCE is shown in Figure 8(B). PCE is lower when thickness of the layer is too small $(0.2 \mu \mathrm{m})$ due to the poor light absorption. PCE of PSCs increases with the increase of the thickness of the absorber 0.20 to $0.40 \mu \mathrm{m}$ before it starts decreasing. For thickness beyond $0.4 \mu \mathrm{m}$, the collection of photo generated carriers decreased because of charge recombination.

The PCE of the device increases when thickness of the absorber layer increases. PCE decreases when thickness is larger than $0.40 \mu \mathrm{m}$. Considering, the effect of thickness of the absorber, the optimized parameters are PCE of $12.83 \%$. $J_{S C}$ of $21.43 \mathrm{~mA} / \mathrm{cm}^{2}, V_{O C}$ of $0.86 \mathrm{~V}$, and FF of $69.51 \%$, as shown in Table 8 . It is evident from literature that pin hole free structure of methyl ammonium lead iodide perovskite can be obtained by using dimethyl sulfoxide (DMSO) and using polyethylene glycol (PEG) also gives a better effects on the surface morphology $[18,43,44]$. By using solvent retarding method (SR), optimal thick and uniform perovskite film can be deposited [45].

\subsection{Performance of Optimized parameters}

At the end, considering all the factors as doping concentration, electron affinity and thickness, we obtained PCE to be $20.42 \%$ with current density of $22.26 \mathrm{mAcm}^{-2}$, voltage of $1.12 \mathrm{~V}$, and fill factor of $82.20 \%$, which shows an improvement of $58.80 \%, 2.25 \%, 20.40 \%$ and $30.23 \%$ in PCE, Jsc, FF and Voc over the initial cell. The final optimized parameters and optimised J-V curve are shown in Table 9 and Figure 9 respectively. We compared our simulated results with the experiment work published by other researchers and the related data is summarized in Table 10.

In the literature, the best efficiency of $11.03 \%$ has been achieved for PSCs with $\mathrm{Cu}_{2} \mathrm{O}$ as HTM. The $V_{O C}$, FF and $J_{S C}$ still need to be increased to achieve $20.42 \%$ efficiency. This could be achieved by further improving the film morphology and crystalline quality of both the absorber and $\mathrm{Cu}_{2} \mathrm{O}$ layer. Doping of $\mathrm{Cu}_{2} \mathrm{O}$ by replacing either part of $\mathrm{Cu}$ or part of $\mathrm{O}$ by other element might/can further modify the charge carrier concentration and mobility of HTM.

\section{Conclusion}

In this work, the lead-based perovskite solar cells with $\mathrm{Cu}_{2} \mathrm{O}$ as HTM are studied by one dimensional simulation programme. The results show that optimum doping concentration in the absorber layer gives improved PCE. High values of doping concentration leads to decrease of PCE due to higher recombination rates. To reduce the recombination rates at the interfaces, proper selection is made for the electron affinity of ETM and HTM. By choosing the electron affinity of ETM as $3.7 \mathrm{eV}$, PCE of PSCs increases from $12.86 \%$ to $20.29 \%$, and by choosing the electron affinity of HTM as $3.3 \mathrm{eV}$, PCE of PSCs increases from $12.86 \%$ to $13.11 \%$. With the optimised thickness of $0.001 \mu \mathrm{m}$, for ETM layer, the PCE of the device increases from $12.86 \%$ to $15.52 \%$. With the optimised HTM thickness of $0.16 \mu \mathrm{m}$, thus, PCE increases up to $12.87 \%$. The overall PCE, FF, $J_{S C}$, and $V_{O C}$, of $20.42 \%, 82.20 \%, 22.26 \mathrm{mAcm}^{-2}$, 
and $1.12 \mathrm{~V}$ respectively were obtained by using all optimised parameters. The results show that $\mathrm{Cu}_{2} \mathrm{O}$ as alternate HTM has the potential to be used with $\mathrm{CH}_{3} \mathrm{NH}_{3} \mathrm{PbI}_{3}$ and can replace the spiro-MeOTAD which is costly HTM for perovskite solar cell.

\section{Acknowledgments}

We thank the referees for the positive enlightening comments and suggestions, which have greatly helped us in making improvements to this paper. The authors would also like to thank Professor Marc Burgelman, Department of Electronics and Information Systems, University of Gent for the development of the SCAPS software package and for allowing its use.

\section{References}

[1] J. S. Manser, \& P. V. Kamat "Band filling with free charge carriers in organometal halide perovskites", Nature Photonics 8 (2014) 737.

[2] H. Chen, F. Ye, W. Tang, J. He, M. Yin, Y. Wang, F. Xie, E. Bi, X. Yang, M. Gratzel, L. Han, "A solvent- and vacuum-free route to large-area perovskite films for efficient solar modules", Nature $\mathbf{5 5 0}$ (2017) 92.

[3] G. Xing, N. Mathews, S. Sun, S. S. Lim, Y. M. Lam, M. Gratzel, S. Mhaisalkar, T. C. Sum, "Long-range balanced electron and hole-transport lengths in organic-inorganic $\mathrm{CH}_{3} \mathrm{NH}_{3} \mathrm{PbI}_{3}$ ", Science 342 (2013) 344.

[4] M. Liu, M. B. Johnston, \& H. J. Snaith, "Efficient planar heterojunction perovskite solar cells by vapour deposition", Nature 501 (2013) 395.

[5] Z. Wang, Q. Lin, F. P. Chmiel, N. Sakai, L. M. Herz, H. J. Snaith, "Efficient ambient-air-stable solar cells with 2D-3D heterostructured butylammonium-caesium-formamidinium lead halide perovskites", Nature Energy 2 (2017) 9.

[6] Y. Liu, Z. Yang, D. Cui, X. Ren, J. Sun, X. Liu, J. Zhang, Q. Wei, H. Fan, F. Yu, X. Zhang, C. Zhao, S. Liu, "Two-inch-sized perovskite $\mathrm{CH}_{3} \mathrm{NH}_{3} \mathrm{PbX}_{3}(\mathrm{X}=\mathrm{Cl}, \mathrm{Br}, \mathrm{I})$ crystals: growth and characterization", Advanced Materials 27 (2015) 5176.

[7] D. Yang, Z. Yang, W. Qin, Y. Zhang, S. Liu, C. Li, "Alternating precursor layer deposition for highly stable perovskite films towards efficient solar cells using vacuum deposition", Journal of Materials Chemistry A 3 (2015) 9401.

[8] S. Yakunin, D. N. Dirin, Y. Shynkarenko, V. Morad, I, Cherniukh, O. Nazarenko, D. Kreil, T. Nauser, M. V. Kovalenko, "Detection of gamma photons using solution-grown single crystals of hybrid lead halide perovskites"', Nature Photonics 10 (2016) 585.

[9] F. Hao, K. Stoumpos, D. H. Cao, R. P. H. Chang, M. Kanatzidis, "Leadfree solid-state organic-inorganic halide perovskite solar cells", Nature Photonics 8 (2014) 489.

[10] Y. Shao, Z. Xiao, C. Bi, Y. Yuan, \& J. Huang, "Origin and elimination of photocurrent hysteresis by fullerene passivation in $\mathrm{CH} 3 \mathrm{NH} 3 \mathrm{PbI} 3$ planar heterojunction solar cells", Nature Communications 5 (2015) 5784.

[11] H. Wei, Y. Fang, P. Mulligan, W. Chuirazzi, H. Fang, C. Wang, B. R. Ecker, Y. Gao, M. A. Loi, L. Cao, J. Huang, "Sensitive X-ray detectors made of methylammonium lead tribromide perovskite single crystals", Nature Photonics 10 (2016) 333.

[12] I. Chung, B. Lee, J. He, R. P. H Chang \& M. G. Kanatzidis, "All-solidstate dye-sensitized solar cells with high efficiency", Nature 485 (2012) 486.

[13] Y. C. Kim, K. H. Kim, D. Y. Son, D. N. Jeong, J. Y. Seo, Y. S. Choi, I. T. Han, S. Y. Lee, N. G. Park, "Printable organometallic perovskite enables large-area, lowdose X-ray imaging", Nature 550 (2017) 87.

[14] Y. Liu, Y. Zhang, Z. Yang, D. Yang, X. Ren, L. Pang, S. F. Liu, "Thinnessand shape-controlled growth for ultrathin singlecrystalline perovskite wafers for mass production of superior photoelectronic devices", Advanced Materials 28 (2016) 9204.

[15] P. Gao M. Gratzel and M. K. Nazeeruddin, "Organohalide lead perovskites for photovoltaic applications", Energy and Environmental Science 7 (2014) 2448.
[16] W.S Yang, B. M. Park, E. H. Jung, N. J. Jeon, Y. C. Kim, D. U. Lee, S. S. Shin, J. Seo, E. K. Kim, J. H. Noh, S. I. Seok, "Iodide management in formamidinium-lead-halide-based perovskite layers for efficient solar cells", Science 356 (2017) 1376.

[17] K. T. Cho, S. Paek, G. Grancini, C. R. Carmona, P. Gao, Y. Lee, M K. Nazeeruddin, "Highly efficient perovskite solar cells with a compositionally engineered perovskite/hole transporting material interface", Energy and Environmental Science 10 (2017) 621.

[18] S. Z. Haider, H. Anwar and M. Wang, "A comprehensive device modelling of perovskite solar cell with inorganic copper iodide as hole transport material", Semiconductor Science and Technology 33 (2018) 12.

[19] N. Rajamanickam, S. Kumari, V. K. Vendra, B. W. Lavery, J. Spurgeon, T. Druffel, and M.K. Sunkara, "Stable and durable $\mathrm{CH}_{3} \mathrm{NH}_{3} \mathrm{PbI}_{3}$ perovskite solar cells at ambient conditions", Nanotechnology 27 (2016) 235404.

[20] K. G. Lim, H. B. Kim, J. Jeong, H. Kim, J. Y. Kim, and T. W. Lee, "Boosting the power conversion efficiency of perovskite solar cells using self-organized polymeric hole extraction layers with high work function", Advanced Materials 26 (2014) 6461.

[21] D. Wang, M. Wright, N. K. Elumalai, and A. Uddin, "Stability of perovskite solar cells", Solar Energy Materials and Solar Cells 147 (2016) 255.

[22] W. Li, H. Dong, L. Wang, N. Li, X. Guo, J. Li, Y. Qiu, "Montmorillonite as bifunctional buffer layer material for hybrid perovskite solar cells with protection from corrosion and retarding recombination", Journal of Materials Chemistry A 2 (2014) 13587.

[23] R.S. Sanchez, and E. Mas-Marza, "Light-induced effects on SpiroOMeTAD films and hybrid lead halide perovskite solar cells", Solar Energy Materials Solar Cells 158 (2016) 189.

[24] X. Zhao, and N-G. Park, "Stability issues on perovskite solar cells", Photonics 2 (2015) 1139.

[25] W. Chen, Y. Wu, Y, Yue, J. Liu, W. Zhang, X. Yang, H. Chen, E. Bi, I. Ashraful, M. Gratzel, L. Han, "Efficient and stable large-area perovskite solar cells with inorganic charge extraction layers", Science 350 (2015) 944.

[26] Y. Hou, X. Du, S. Scheiner, D. P. McMeekin, Z. Wang, N. Li, M. S. Killian, H. Chen, M. Richter, I. Levchuk, N. Schrenker, E. Spiecker, T. Stubhan, N. A. Luechinger, A. Hirsch, P. Schmuki, H. P. Steinruck, R. H. Fink, M. Halik, H. J. Snaith, C. J. Brabec, "A generic interface to reduce the efficiency-stability-cost gap of perovskite solar cells", Science $\mathbf{3 5 8}$ (2017) 1192

[27] G. Grancini, C. Roldan-Carmona, I. Zimmermann, E. Mosconi, X. Lee, D. Martineau, S. Narbey, F. Oswald, F. De Angelis, M. Gratzel, M. K. Nazeeruddin, "One-year stable perovskite solar cells by 2D/3D interface engineering", Nature Communications 8 (2017) 15684.

[28] A. Mei, X. Li, L. Liu, Z. Ku, T. Liu, Y. Rong, M. Xu, M. Hu, J. Chen, Y. Yang, M. Gratzel, H. Han, "A hole-conductor-free fully printable mesoscopic perovskite solar cell with high stability", Science 345 (2014) 295.

[29] N. Arora, M. I. Dar, A. Hinderhofer, N. Pellet, F. Schreiber, S. M. Zakeeruddin, M. Gratzel, "Perovskite solar cells with $\mathrm{CuSCN}$ hole extraction layers yield stabilized efficiencies greater than $20 \%$ ". Science 358 (2017) 768.

[30] W. Yu, F. Li, H. Wang, E. Alarousu, Y. Chen, B. Lin, L. Wang, M. N. Hedhili, Y. Li, K. Wu, X. Wang, O. F. Mohammed and T. Wu, "Ultrathin $\mathrm{Cu}_{2} \mathrm{O}$ as an efficient inorganic hole transporting material for perovskite solar cells", Nanoscale 8 (2016) 6173.

[31] Y.J. Chen, M.H. Li, J.C.A. Huang, \& P. Chen, " $\mathrm{Cu} / \mathrm{Cu}_{2} \mathrm{O}$ nanocomposite films as a p-type modified layer for efficient perovskite solar cells", Scientific Reports 8 (2018) 7646.

[32] R Wei, "Modelling of Perovskite Solar Cells", M.Sc Degree Thesis, Queensland University of Technology 2018.

[33] M. I. Hossain, F. H. Alharbi, and N. Tabet, "Copper oxide as inorganic hole transport material for lead halide perovskite based solar cells", Solar Energy 120 (2015) 370.

[34] K. Tan, P. Lin, G. Wang, Y. Liu, Z. Xu, and Y. Lin, "Controllable design of solid-state perovskite solar cells by SCAPS device simulation", Solid State Electron 126 (2016) 75.

[35] M. Amalina, and M. Rusop. "Morphological, electrical and optical properties of $\gamma$-copper (I) iodide thin films by mist atomization technique", World Journal of Engineering 9 (2012) 251.

[36] U. Mandadapu, S. V. Vedanayakam , and K. Thyagarajan, "Simulation and analysis of lead based perovskite solar cell using SCAPS-1D”, Indian 
Journal of Science Technology 10 (2017) 1.

[37] K. G. Lim, S. Ahn, H. Kim, M. R. Choi, D. H. Huh, and T. W. Lee, "Selfdoped conducting polymer as a hole-extraction layer in organic-inorganic hybrid perovskite solar cells", Advanced Materials Interfaces 3 (2016) 1500678.

[38] Q. Wang, Y. Shao, H. Xie, L. Lyu, X. Liu, Y. Gao, and J. Huang, "Qualifying composition dependent $\mathrm{p}$ and n self-doping in $\mathrm{CH}_{3} \mathrm{NH}_{3} \mathrm{PbI}_{3}$ ", Applied Physics Letters 105 (2014) 163508.

[39] L. A. Frolova, N. N. Dremova, and P. A. Troshin, "The chemical origin of the p-type and n-type doping effects in the hybrid methylammonium-lead iodide $\left(\mathrm{MAPbI}_{3}\right)$ perovskite solar cells", Chemical Communication $\mathbf{5 1}$ (2015) 14917.

[40] C. S. Jiang, M. Yang, Y. Zhou, B. To, S. U. Nanaakkara, J. M. Luther, W. Zhou, J. J. Berry, J. V. de Lagemaat, N. P. Padture, K. Zhu, M. M. Aljassim, "Carrier separation and transport in perovskite solar cells studied by nanometre-scale profiling of electrical potential", Nature Communications 6 (2015) 8397.
[41] U. Thakur, R. Kisslinger, and K. Shankar, "One-dimensional electron transport layers for perovskite solar cells", Nanomaterials 7 (2017) 1.

[42] K. G. Lim, S. Ahn, Y. H. Kim, Y. Qi, and T. W. Lee, "Universal energy level tailoring of self-organized hole extraction layers in organic solar cells and organic-inorganic hybrid perovskite solar cells Energy and Environmental Science 9 (2016) 932.

[43] N. J. Jeon, J. H. Noh, Y. C. Kim, W. S. Yang, S. Ryu and S. Seok, "Solvent engineering for high-performance inorganic-organic hybrid perovskite solar cells", Nature Materials 13 (2014) 897.

[44] M. I. Ahmed, A. Habib and S. S Javaid, "Perovskite solar cells: potentials, challenges, and opportunities", International Journal of Photoenergy 2015 (2014) 1

[45] Z. Yuan, Y. Yang, Z. Wu, S. Bai, W. Xu, T. Song, X. Gao, F. Gao, and B. Sun, "Approximately $800 \mathrm{~nm}$ thick inhole-free perovskite films via facile solvent retarding process for efficient planar solar cells", ACS Applied Materials Interfaces 8 (2016) 34446. 